\title{
IMMUNOGENICITY ASSAY OF KatG PROTEIN FROM Mycobacterium tuberculosis IN MICE: PRELIMINARY SCREENING OF TB VACCINE
}

\author{
P. PURKAN $N^{1 \otimes}$, R. BUDIYANTO', R. AKBAR ${ }^{1}$, \\ S. P. A. WAHYUNINGSIH ${ }^{2}$, W. RETNOWATI ${ }^{3}$ \\ ${ }^{1}$ Biochemistry Division, Chemistry Department, Faculty of Sciences and Technology, \\ Airlangga University, Campus C, Jl. Mulyorejo-Surabaya, Indonesia; \\ ${ }^{2}$ Biology Department, Faculty of Sciences and Technology, Airlangga \\ University, Campus C, Jl. Mulyorejo-Surabaya, Indonesia; \\ ${ }^{3}$ Microbiology Department, Faculty of Medicine, Airlangga University, \\ Campus C, Jl. Moestopo-Surabaya, Indonesia; \\ 凶e-mail: purkan@fst.unair.ac.id
}

The tuberculosis (TB) disease is still widely found even though BCG vaccine given to many people. Ineffectiveness of the BCG vaccine is one of causes that make the difficulties in preventing TB transmission. Objective of the research was to determine the immunogenicity of KatG protein of M. tuberculosis clinical isolate L19 in mice. The KatG protein as antigen was prepared by expression of the katG gene of M. tuberculosis clinical isolate L19 in Escherichia coli BL21 using pColdII-DNA vector. After purification by affinity chromatography, the KatG was vaccinated to mice to detect its immunogenicity. The expression of katG in E. coli BL21 could result in KatG protein with molecular weight $80 \mathrm{kDa}$ in sodium dodecyl sulfate gel electrophoresis (SDS-PAGE). The pure KatG protein could significantly stimulate the immune response of mice by triggering the antibodies production of IgG1, IgG2a, IgG2b, IgG2c, IgG3, and IgM. The highest antibody level was obtained when the mice were vaccinated by KatG L19 with the dose of $45 \mu \mathrm{g} / \mathrm{ml}$. Of the antibodies, the IgG2c isotype was dominantly produced in the blood serum. The KatG protein exhibited a high immunogenicity in mice, so it is possible to develop as a vaccine candidate for TB. A clinical test should be performed in a future to ensure its safety as a therapeutic protein.

Ke ywords : KatG, immunogenicity, M. tuberculosis, vaccine, clinical isolate.

$\mathrm{T}$ uberculosis (TB) is a major health problem throughout the world causing a large number of deaths, more than any other single infectious disease, that is caused by Mycobacterium tuberculosis infection. There were strategies to reduce the spread of TB including the use of Anti TB therapeutic, but the pandemics of Multidrug-Resistant TB (MDR TB) have emerged since 1990 that causing TB more difficult to treat [1]. Tuberculosis control with preventive actions through the development of a vaccine became one of the main concerns in current TB control program. Bacillus Calmette Guerin (BCG) is a TB vaccine that contains live bacteria that have been weakened (attenuated), it can stimulate the immune system but do not cause disease in healthy people. The BCG vaccine can not be given to people who are clinically immunosuppressed [2]. The BCG is currently used in many countries with a high prevalence of TB to prevent childhood tuberculous meningitis and miliary disease [3]. It is also approved by the FDA for vaccination against tuberculosis and for the treatment of bladder cancer [4]. In spite of the BCG vaccine is used throughout the world, the facts showed BCG is still not effective because the TB cases are still high. The protection provided by BCG varies widely from $0-80 \%$, then it continuously decrease up to $17 \%$ in the next 15 years [1]. In an effort to answer those problems, is necessary to develop a new TB vaccine.

(C) 2018 Purkan P. et al. This is an open-access article distributed under the terms of the Creative Commons Attribution License, which permits unrestricted use, distribution, and reproduction in any medium, provided the original author and source are credited. 
DNA vaccine encoding the type of protein naturally EAST - 6 and KatG has been tested on mice and it reported to increase the immune response in the mouse cells producing antibodies, then they were classified as intracellular pathogenic proteins. Although DNA vaccine may provide an immune response that is quite good, the use of a DNA vaccine becomes ineffective if the DNA cannot be expressed into proteins in the host cell. Therapeutic proteins and peptides have the potential to elicit immune responses resulting in anti-drug antibodies [5].

The kat $G$ gene from $M$. tuberculosis clinical isolate L19 has been cloned in in Escherichia coli using - DNA vector [6]. The gene that encodes an intracelular protein with molecular weight $80 \mathrm{kDa}$ has been reported as one of pathogenic intracelular protein [6-9]. The KatG is also classified by TubercuList as a virulence factor that participates in the response to stress and host oxidative reactions. The KatG protein also represents a catalase-peroxidase of Rv1908c which is grouped as one of the surface-exposed proteins that is involved in cell wall biogenesis and maintenance $[10,11]$. The surface-exposed proteins are excellent targets for the host adaptive immune system, so they are potentially used for the development of vaccines for mycobacterial disease [10]. The katG gene expression is needed to provide its protein, then further used to search its potential as TB vaccine.

The effectiveness of a vaccine depends upon the level of specificity of protein antigens to induce the immune system to produce specific antibodies, so it is necessary to create a pure protein to be used as a vaccine. Immunogenicity of protein vaccine candidate should be investigated in the target population since animal testing and in vitro models cannot predict immune response in humans. In addition, immunogenicity has a role in demonstrating product comparability following manufacturing changes and similarity in the context of biosimilar development [11]. Currently, detection of a product's immunogenicity involves measuring antibodies specifically generated against the vaccine candidate. The vaccine is said to be ideal if the concentration is low enough effective to induce high antibody production and be able to induce the formation of a specific type of antibody which has a half-length.

Immunogenicity of KatG L19 protein from Mycobacterium tuberculosis has been unknown. Based on the case, it was made the purification of crude extract of KatG protein from Mycobacterium tuberculosis local clinical isolate and followed by the immunogenicity assay in mice. The immunogenicity test was conducted to determine the presence (or absence) of antibodies based on the ability of the antibodies to recognize the KatG protein in mice. Additionally, it was also prepared to detect antibodies with desired specificities such as IgM, IgG subclasses etc [5].

\section{Materials and Methods}

Samples. The Escherichia coli BL21 (DE3) carrying of pCold II-katG L19 recombinant was obtained from the laboratory of Biochemistry, Faculty of Sciences and Technology, Airlangga University, used to produce the KatG protein. Female mice Mus musculus strain Balb/C, 8-10 weeks old, weighing 25-30 gr, were obtained from the PUSVETMA Surabaya.

Expression of KatG protein. The recombinant of E. coli [pCold II-katG L19] was cultured in Luria Bertani (LB) medium composed of 0,5\% (w/v) yeast extract, $1 \%(\mathrm{w} / \mathrm{v})$ tryptone, $1 \%(\mathrm{w} / \mathrm{v}) \mathrm{NaCl}$ and $100 \mu \mathrm{g} / \mathrm{ml}$ of ampicillin, shaking it at $150 \mathrm{rpm}$ and at a temperature of $37^{\circ} \mathrm{C}$ until obtained the optical density of cells $0.5-0.6$ at $\lambda 600 \mathrm{~nm}$ [6-8]. The culture was then moved to incubator at $15^{\circ} \mathrm{C}$ for $30 \mathrm{~min}$ without shaking, added with $0.1 \mathrm{mM}$ IPTG and reincubated at $15^{\circ} \mathrm{C}$ with shaking speed at $150 \mathrm{rpm}$ for 24 hours. The cells were separated by centrifugation at $5.000 \mathrm{~g}$ at $4{ }^{\circ} \mathrm{C}$ for $10 \mathrm{~min}$, and washed with lysis buffer (50 mM Tris-Cl pH 7.4; $200 \mathrm{mM} \mathrm{NaCl}$ ), and centrifugated at $5.000 \mathrm{~g}$ at $4{ }^{\circ} \mathrm{C}$ for $10 \mathrm{~min}$. The cell pellet was resuspended in $7-10 \mathrm{ml}$ of $0.02 \mathrm{M}$ phosphate buffer $\mathrm{pH} 7$ and lysed in the sonicator at $60 \mathrm{~Hz}$ for $10 \mathrm{~min}$. The supernatant containing of KatG was centrifuged at $10.000 \mathrm{~g}$ in $4{ }^{\circ} \mathrm{C}$ for 20 minutes and stored at $-20{ }^{\circ} \mathrm{C}$ [6-8].

Protein purification. Purification of KatG protein was carried out by affinity chromatography method using HisTrap HP column containing Ni-Sepharose matrix. Protein sample first setted to pH 7.4 in sodium phosphate buffer containing 25$50 \mathrm{mM} \mathrm{NaCl}$ and $10 \mathrm{mM}$ imidazol. Before the protein sample was filled in HisTrap column, first the column was washed and balaced respectively with milli-Q water and binding buffer $\left(50 \mathrm{mM} \mathrm{NaH}_{2} \mathrm{PO}_{4}\right.$ $\mathrm{pH} 7.4,25 \mathrm{mM} \mathrm{NaCl}, 10 \mathrm{mM}$ imidazole) as much as 5 times of the column volume. After protein sample was flowed in column, the liquid that came out of the column was accommodated. The protein was eluted with binding buffer containing of 50-200 mM imi- 
dazole $[6,9]$. Each fraction was accommodated per $1 \mathrm{ml}$, then the presence of KatG protein in the fraction was detected by sodium dodecyl sulfate - polyacrylamide gel electrophoresis. (SDS PAGE) [6, 8].

SDS-PAGE. The KatG protein was analyzed by SDS PAGE using $12 \%(\mathrm{w} / \mathrm{v})$ and $4 \%(\mathrm{w} / \mathrm{v})$ acrylamide for separating and stacking gel respectively based on Sambrook method [12].

Protein Concentration Assay. A total of $5 \mu \mathrm{l}$ protein sample coupled with $795 \mu$ l of distilled water, then added with Bradford reagent until a final volume of $1 \mathrm{ml}$. After the mixture was incubated for 5 min at room temperature, the absorbance of the mixture was read by UV-Vis spectrophotometer at $595 \mathrm{~nm}$. The BSA was used as standar in the assay [12].

Production of Antibody. Activation as a vaccine. The KatG protein as antigen protein was added with complete Freund's adjuvant (CFA) (ratio $1: 1$ ), then mixed in vortex for 30 mins. The active antigen protein was further used as a vaccine for the experimental animal $[12,14]$.

Mice immunization and serum isolation. Immunization was done three times to female mice $\mathrm{Balb} / \mathrm{C}$, aged 8-10 weeks with KatG antigen. The work was clustered in 4 treatments with 6 repetitions. First immunization, the mice were injected intraperitoneally by mixture of KatG in varing concentration 5, 15, and $45 \mu \mathrm{g} / \mathrm{ml}$ with CFA (ratio $1: 1$ ) in total volume of $100 \mu \mathrm{l}$. For control, it was used 6 mice with a strain, sex, and the same age, but injected with phosphate buffer saline (PBS) without antigen. The second immunization was done 14 days after the first immunization. The mice were injected by a mixture of KatG with incomplete Freud's adjuvant (ICFA) in the ratio $1: 1$. The third immunization was completed after 28 days, and the mice were only injected by KatG antigen in PBS without adjuvant [12-14].

Five days after the last immunization, the blood of the mice was drawn from their heart, then collected into tubes and stand at room temperature for $2 \mathrm{~h}$ to coagulate the red blood cells. Furthermore, the blood was centrifuged at $3000 \mathrm{rpm}$ at $4{ }^{\circ} \mathrm{C}$ for $10 \mathrm{~min}$. Serum was collected to measure the antibody titers and serotyping assay $[12,15]$.

Determination of antibody content. The measurements of antibody levels was detected with Protein Detector ${ }^{\mathrm{TM}}$ Peroxidase ELISA Kits, KPL Inc. One hundred $\mu 1$ of recombinant proteins was filled in the microplate with 96 wells, incubated at $4{ }^{\circ} \mathrm{C}$ for 24 hours to coat the plate well, then added with $200 \mu \mathrm{l} 10 \%(\mathrm{w} / \mathrm{v})$ of BSA as blocking reagent and re-incubated for $15 \mathrm{~min}$ at room temperature. To each of the wells was added $100 \mu \mathrm{L}$ of primary antibody in PBS derived from serum, then incubated at room temperature for 1 hour and followed by washing the each well with $300 \mu$ wash solution. To each of the wells was added with $100 \mu \mathrm{l}$ of HRP - anti-mouse IgG conjugate and incubated for $1 \mathrm{~h}$ at room temperature, then washed with $300 \mu \mathrm{l}$ wash solution and repeated three times. Additionally, each of the wells was added $100 \mu$ l substrate of 3,3'5,5'-tetramethylbenzidine (TMB). Finally, it was added $100 \mu \mathrm{l}$ stop solution to every well. Optical density of antibody was measured at $450 \mathrm{~nm}$ $[12,13,15]$.

Antibody isotyping assay. The $100 \mu \mathrm{l}$ of serum samples and positive control working solution filled respectively to the test samples wells, then it sealed by a cover and incubated at $37^{\circ} \mathrm{C}$ for $90 \mathrm{~min}$. Subsequently, the cover was removed and the plate content discharged. The $100 \mu \mathrm{l}$ of biotin - Anti mouse IgG1, IgG2a, IgG2b, IgG2c, IgG3 and IgM antibodies working solution was added to the test samples wells respectively. The 6 Biotin - antibodies were also reacted to the positive control. The plate was sealed with a cover and incubated at $37^{\circ} \mathrm{C}$ for $60 \mathrm{~min}$. Subsequently, the cover was removed and plate washed 3 times with wash buffer. The $100 \mu \mathrm{l}$ of HRP - Streptavidin Conjugate (SABC) working solution was added to each well, the the plate was covered and incubated at $37{ }^{\circ} \mathrm{C}$ for $60 \mathrm{~min}$. The cover was removed, and plate washed 5 times with wash buffer. The $90 \mu 1$ of TMB substrate was added to each well and incubated at $37{ }^{\circ} \mathrm{C}$ in dark within $15 \mathrm{~min}$. The $50 \mu \mathrm{l}$ of stop solution was added to each well and mix thoroughly. The absorbance of yellow product was recorded at a wavelength $(\lambda)$ of $450 \mathrm{~nm}$ $[12,15,24]$.

\section{Results and Discussion}

The best and potential antigens for subunit vaccine against $\mathrm{TB}$ are continuously sought after sequencing of the $M$. tuberculosis genome. However the antigen candidate should be released by intracellular mycobacteria which has many promiscuous epitopes to be presented to MHC class I and MHC class II, and can emerge a strong Ag-specific type 1 immune response [16-20]. This paper showed that KatG of $M$. tuberculosis has a potential antigen for vaccine candidate, because it can induce a high antibody response in the experimental animal. 


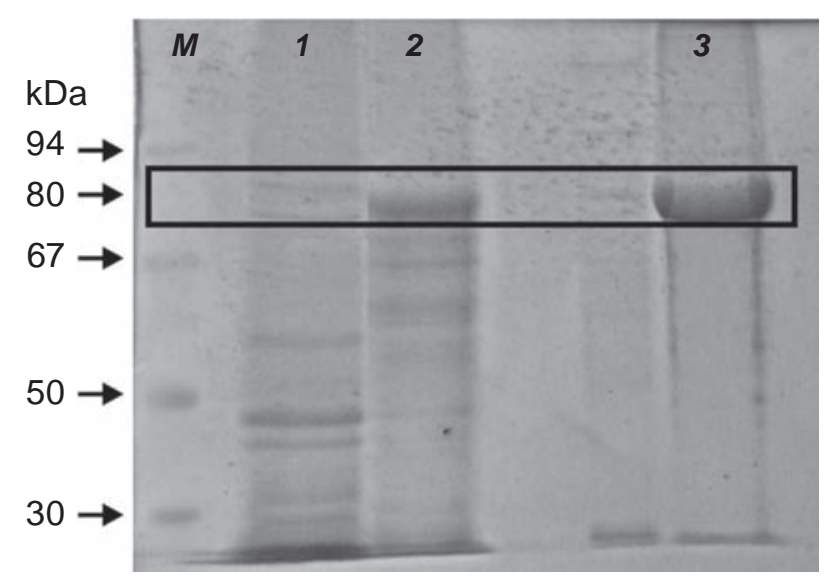

Fig. 1. Profile of KatG L19 protein in SDS-PAGE electropherogram before and after purified by affinity chromatoghraphy method. Lane $M$, protein marker; lane 1, extract of protein from E. coli had no a katG recombinant; lane 2, extract of protein from E. coli containing a katG recombinant; lane 3, pure KatG protein $(80 \mathrm{kDa}$ ) after eluted with $150 \mathrm{mM}$ imidazole from column

The antigen of KatG L19 protein. The KatG protein used for antigen was produced by expression of katG gene (2.2 kb) of M. tuberculosis clinical isolate L19 in E. coli BL21(DE3) using pCold IIDNA vector. The KatG protein $80 \mathrm{kDa}$ was found in extract of E. coli BL21(DE3) recombinant after it analyzed by SDS PAGE. The KatG protein was absent in extract from non recombinant of E. coli BL21(DE3) (Fig. 1, lane 1 and 2). The KatG L19 protein in extract then was purified by using affinity chromatography based on Immobilized Metal Affinity Chromatography (IMAC). The pure of KatG L19 protein resulted a band $80 \mathrm{kDa}$ in SDS-PAGE after the protein extract eluted with sodium phosphate buffer containing $150 \mathrm{mM}$ imidazole (Fig. 1, lane 3). The pure of KatG L19 was further used as antigen for immunization in mice.

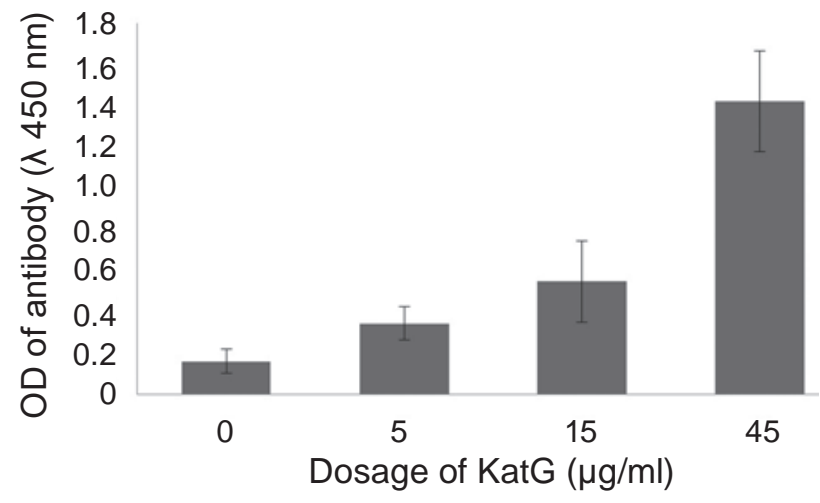

Fig. 2. Grafic of antibody levels produced by mice after injected with KatG L19 in various dosages. The $\mathrm{Kat} G$ with dosage of $45 \mu \mathrm{g} / \mathrm{ml}$ gave a high response for antibody production in mice

\section{Antibody Response of Mice Against to KatG} L19. Immunization of mice with pure KatG L19 protein was performed in various doses 5,15 and $45 \mu \mathrm{g} /$ $\mathrm{ml}$. The antibody product of each threatment was recorded by ELISA method. The KatG can elicite a high antibody response in mice after the experimental animal injected by the protein in various doses. The highest antibody in our research was reached when the mice vaccinated by KatG L19 in the dose of $45 \mu \mathrm{g} / \mathrm{ml}$ (Table and Fig. 2). Antibody response against to KatG at various doses of $0,5,15$ and $45 \mu \mathrm{g} / \mathrm{ml}$ showed a significant differences among all treatments. The Anova and Duncan tests also confirmed the differences with score of $P<0.05$, except for antibody product from the KatG antigen with doses 0 and $5 \mu \mathrm{g} / \mathrm{ml}$ (Table).

The optimal of antigen doses is a crutial to be investigated in the vaccination process, since the antigen dose significantly affects $\mathrm{T}$ cell functional avidity, differentiation status, and their subsequent protection against TB. Optimal protective capacity of T cells against $M$. tuberculosis infection relies on

The optical density $\left(O D_{450 n m}\right)$ of antibody response in mice after injected by KatG L19 in various doses

\begin{tabular}{|c|c|c|c|c|c|c|c|c|}
\hline \multirow{2}{*}{ Treatment } & \multicolumn{6}{|c|}{ Repetition } & \multirow{2}{*}{$\begin{array}{c}\text { everage } \\
(\chi)\end{array}$} & \multirow{2}{*}{ SD } \\
\hline & 1 & 2 & 3 & 4 & 5 & 6 & & \\
\hline $0 \mu \mathrm{g} / \mathrm{ml}$ & 0.266 & 0.112 & 0.172 & 0.160 & 0.141 & 0.107 & 0.159 & $0.057^{\mathrm{a}}$ \\
\hline $5 \mu \mathrm{g} / \mathrm{ml}$ & 0.446 & 0.270 & 0.322 & 0.252 & 0.340 & 0.430 & 0.343 & $0.080^{\mathrm{a}}$ \\
\hline $15 \mu \mathrm{g} / \mathrm{ml}$ & 0.633 & 0.335 & 0.477 & 0.419 & 0.896 & 0.521 & 0.546 & $0.197^{\mathrm{b}}$ \\
\hline $45 \mu \mathrm{g} / \mathrm{ml}$ & 1.824 & 1.192 & 1.373 & 1.170 & 1.557 & 1.424 & 1.423 & $0.244^{\mathrm{c}}$ \\
\hline
\end{tabular}

The test of ANOVA and Duncan presented a significance difference when the p score achieved at least $5 \%$. No significant difference of antibody product was found in antigen dosages of 0 and $5 \mu \mathrm{g} / \mathrm{ml}$, whereas the others had significant value 


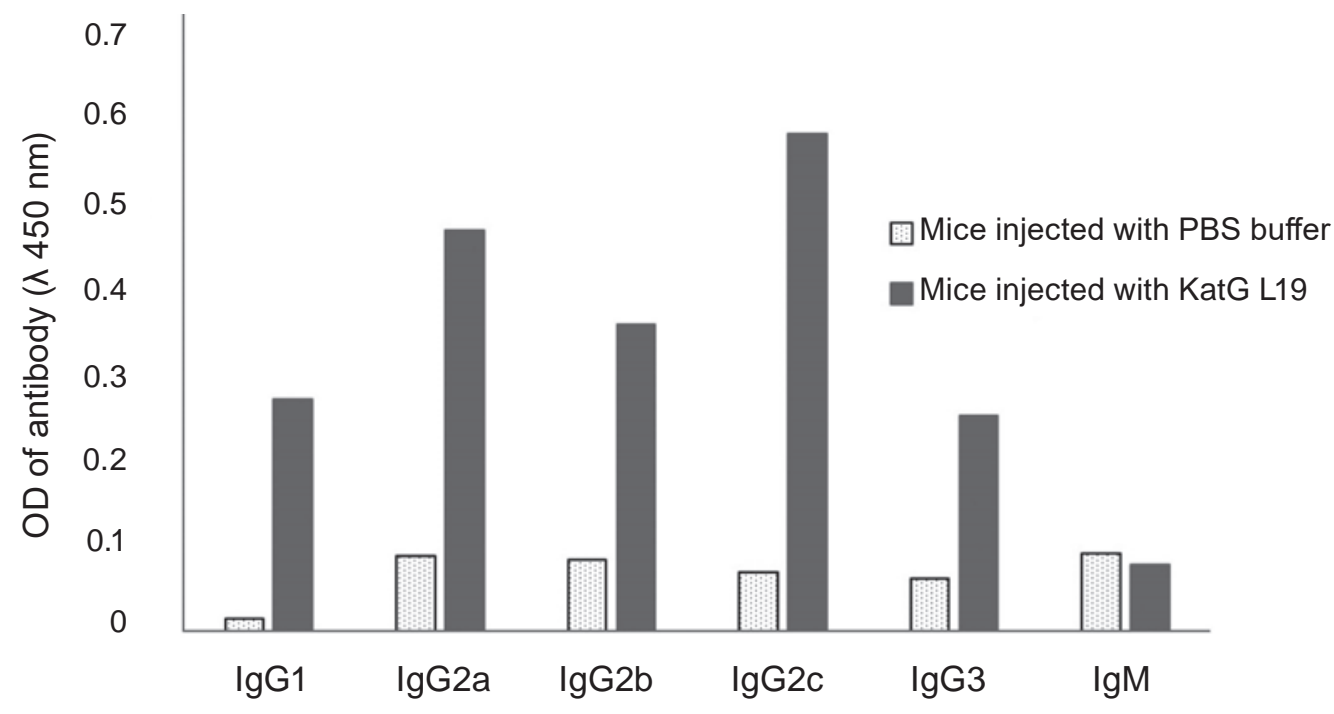

Fig. 3. Histograme of antibody types which produced by mice with present and absent of KatG L19 protein. The KatG L19 protein induced significantly the production of $\operatorname{Ig} G 1, \operatorname{Ig} G 2 a, \operatorname{Ig} G 2 b, \operatorname{Ig} G 2 c, \operatorname{Ig} G 3$ in mice

the ability of $\mathrm{T}$ cells to home into the lung parenchyma to make close contact with granuloma resident Mtb-infected host cells. The quality of T cells becomes very important in the protection of tuberculosis vaccines which provided by a significant role of antigen doses in vaccine-mediated protection [11].

Immunogenicity profile of KatG L19. The imunogenicity analysis of KatG requires information of the present specific immunoglobulin of IgG in serum which does a main role against to pathogens. In human, the immunoglobulin is the most abundant antibody isotype which found in the circulation and provide the majority of antibody-based immunity against invading pathogens [21-23].

The KatG which injected in mice stimulated the expression of six antibody types, i.e IgG1, IgG2a, IgG2b, IgG2c, IgG3 and IgGM. Of the antibodies, the $\operatorname{IgG} 2 \mathrm{c}$ and $\operatorname{IgG} 2 \mathrm{a}$ isotypes emerged higher that other, whereas $\operatorname{IgM}$ was expressed in the lowest content (Fig. 3). The first and second highest OD of immunoglobulin were found on the type $\operatorname{IgG} 2 \mathrm{c}$ and $\mathrm{IgG} 2 \mathrm{a}$ isotypes in all treatment groups for KatG doses of 5,15 or $45 \mu \mathrm{g} / \mathrm{ml}$. The data suggest that KatG elicits a high immunogenicity effect through the formation of $\mathrm{IgG}$ which is subsequently used to realize an immune response, so it is a possible to be deveoped as vaccine candidate in future.

The IgM antibody was produced quite a bit in mice after it immunized by KatG for 35 days. The
IgM is classified as the first-line antibody for defense against infection from antigen proteins. High production of $\operatorname{IgM}$ can occur when the first week of infection, then decrease in the remaining weeks $[17,23]$. Because of the blood isolation in this study was performed on day 35, so the obtained IgM level was low. The IgG2c and IgG2a subclasses were the highest immunoglobulin that appears in blood serum of mice, this might be due to their abilities to respond antigen proteins. Immunohistochemistry assay is developed in future to detect the lymphocytes level of CD4 and CD8 to provide well on the relationship of the antibody response with the number of lymphocyte cells.

Conclusion. The KatG L19 from clinical isolate of $M$. tuberculosis stimulate significantly immune response in mice to produce antibody. The protein induces the formation of immunoglobulin IgG1, IgG2a, IgG2b, IgG2c, IgG3, and IgM, where the IgG2c isotype produced dominantly. The high immunogenic exposed by KatG L19 encourages its development as a protein candidate for TB vaccine, so it needs to develope a clinical testing for the protein in future.

Acknowledgements. This research was funded from DIPA Ditlitabmas, Ministry of Research and Technology, Republic of Indonesia, contract number 951/UN3.14/LT/2016. 


\section{АНАЛІЗ ІМУНОГЕННОСТІ ПРОТЕÏHУ KatG I3 Mycobacterium tuberculosis У МИШЕЙ: ПОПЕРЕДНІЙ СКРИНІНГ ВАКЦИНИ ТВ}

P. Purkan ${ }^{1 \bowtie}$, R. Budiyanto ${ }^{1}$, R. Akbar ${ }^{1}$, S. P. A. Wahyuningsih ${ }^{2}$, W. Retnowati ${ }^{3}$

${ }^{1}$ Biochemistry Division, Chemistry Department, Faculty of Sciences and Technology, Airlangga University,

Campus C, Jl. Mulyorejo-Surabaya, Indonesia;

${ }^{2}$ Biology Department, Faculty of Sciences and

Technology, Airlangga University, Campus C, J1. Mulyorejo-Surabaya, Indonesia; ${ }^{3}$ Microbiology Department, Faculty of Medicine, Airlangga University, Campus C, Jl. Moestopo-Surabaya, Indonesia;

凶e-mail: purkan@fst.unair.ac.id

Туберкульоз залишається одним із поширеніших захворювань, хоча багато людей пройшли вакцинацію БЦЖ. Неефективність вакцини БЦЖ $є$ однією з причин, які ускладнюють профілактику поширення туберкульозу. Метою дослідження було визначення імуногенності протеїну KatG в клінічному ізоляті L19 штаму $M$. tuberculosis у мишей. KatG, як антиген, отримували експресією гена katG клінічного ізоляту L19 M. tuberculosis в Escherichia coli BL21 iз використанням вектора pColdII-DNA. KatG після очищення афінною хроматографією використовували для вакцинації мишей. Експресією katG в E. coli BL21 одержували протеїн KatG iз молекулярної масою 80 кДа за електрофорезу на PAGE-SDS. Очищений протеїн KatG значно стимулював імунну відповідь мишей, спричинюючи продукування антитіл IgG1, IgG2a, IgG2b, $\mathrm{IgG} 2 \mathrm{c}, \operatorname{IgG3}$ і IgM. Найвищий рівень антитіл спостерігали у разі вакцинації мишей KatG L19 в дозі 45 мкг/мл. Серед антитіл IgG2c-ізотип переважно продукувався в сироватці крові. Показано, що протеїн KatG виявляє високу імуногенність у мишей і може бути запропонований як потенціальна вакцина проти туберкульозу. Необхідно в подальшому провести клінічні дослідження для оцінки безпеки його застосування як терапевтичного протеїну.

К л ю чо в і сл ов а: KatG, імуногенність, M. tuberculosis, вакцина, клінічний ізолят.

\section{АНАЛИЗ ИММУНОГЕННОСТИ ПРОТЕИНА KatG ИЗ Mycobacterium tuberculosis У МЫШЕЙ: ПРЕДВАРИТЕЛЬНЫЙ СКРИНИНГ ВАКЦИНЫ ТВ}

\author{
P. Purkan ${ }^{1 凶}$, R. Budiyanto ${ }^{1}$, R. Akbar ${ }^{1}$, \\ S. P. A. Wahyuningsih ${ }^{2}$, W. Retnowati ${ }^{3}$
}

${ }^{1}$ Biochemistry Division, Chemistry Department, Faculty of Sciences and Technology, Airlangga University, Campus C, Jl. Mulyorejo-Surabaya, Indonesia; ${ }^{2}$ Biology Department, Faculty of Sciences and Technology, Airlangga University, Campus C, Jl. Mulyorejo-Surabaya, Indonesia; ${ }^{3}$ Microbiology Department, Faculty of Medicine, Airlangga University, Campus C, Jl. Moestopo-Surabaya, Indonesia; 凶e-mail: purkan@fst.unair.ac.id

Туберкулез остается одним из широко распространенных заболеваний, хотя большинство людей вакцинированы БЦЖ. Неэффективность вакцины БЦЖ является одной из причин, которые затрудняют профилактику распространения туберкулеза. Целью исследования было определение иммуногенности протеина KatG в клиническом изоляте L19 штамма M. tuberculosis у мышей. KatG в качестве антигена получали экспрессией гена $k a t G$ клинического изолята L19 M. tuberculosis в Escherichia coli BL21 с использованием вектора pColdII-DNA. KatG после очистки аффинной хроматографией использовали для вакцинации мышей. Экспрессией katG в E. coli BL21 получали протеин KatG с молекулярной массой 80 кДа при электрофорезе на PAGE-SDS. Очищенный протеин KatG значительно стимулировал иммунный ответ мышей, вызывая продуцирование антител IgG1, IgG2a, $\operatorname{IgG} 2 b, \operatorname{IgG} 2 c, \operatorname{IgG} 3$ и IgM. Самый высокий уровень антител наблюдали при вакцинации мышей KatG L19 в дозе 45 мкг/мл. Среди антител IgG2c-изотип преимущественно продуцировался в сыворотке крови. Показано, что протеин $\mathrm{KatG}$ проявляет высокую иммуногенность у мышей и может быть предложен в качестве потенциальной вакцины против туберкулеза. Необходимо в дальнейшем провести клинические исследования для оценки безопасности его применения в качестве терапевтического протеина.

К л ю че вы е с ло в $\mathrm{a}: \mathrm{KatG}$, иммуногенность, M. tuberculosis, вакцина, клинический изолят. 


\section{References}

1. Tuberculosis in Indonesia - Health and Medical Concerns [Internet]. [cited 2015 November 25]. Available from: http://www.expat.or.id/medical/ tuberculosis.

2. Bold TD, Banaei N, Wolf AJ, Ernst JD. Suboptimal activation of antigen-specific $\mathrm{CD} 4+$ effector cells enables persistence of $\mathrm{M}$. tuberculosis in vivo. PLoS Pathog. 2011; 7(5): e1002063.

3. Maryanne EC, Jay SK. Understanding, Controlling, and Preventing Infectious Diseases. In: Sarah SL, Larry KP, Charles GP, eds. Principles and Practice of Pediatric Infectious Diseases. $4^{\text {th }}$ Ed, United States: Elsevier Inc; 2012: 76-83.

4. Kowalewicz-Kulbat M, Locht C. BCG and protection against inflammatory and autoimmune diseases. Expert Rev Vaccines. 2017; 16(7): 1-10.

5. Li Z, Howard A, Kelley C, Delogu G, Collins F, Morris S. Immunogenicity of DNA vaccines expressing tuberculosis proteins fused to tissue plasminogen activator signal sequences. Infect Immun. 1999; 67(9): 4780-4786.

6. Purkan, Ihsanawati, Syah YM., Retnoningrum DS, Noer AS., Shigeoka S, Natalia D. Novel mutations in katG gene of a clinical isolate of isoniazidresistant Mycobacterium tuberculosis. Biologia. 2012; 67(1): 41-47.

7. Purkan, Ihsanawati, Natalia D, Syah YM, Retnoningrum DS, Kusuma HS. Mutation of katG in a clinical isolate of Mycobacterium tuberculosis: effects on catalase-peroxidase for isoniazid activation. Ukr Biochem J. 2016; 88(5): 71-81.

8. Purkan P, Wahyuningsih SPA, Retnowati W, Amelia D, Alimny AN. Structure - Activity Relationship of Mutant KatG from INH resistant Mycobacterium tuberculosis. J Pure Appl Microbiol. 2017; 11(2): 695-701.

9. Wengenack NL, Lane BD, Hill PJ, Uhl JR, Lukat-Rodgers GS, Hall L, Roberts GD, Cockerill FR 3rd, Brennan PJ, Rodgers KR, Belisle JT, Rusnak F. Purification and characterization of Mycobacterium tuberculosis KatG, KatG(S315T), and Mycobacterium bovis KatG(R463L). Protein Expr Purif. 2004; 36(2): 232-243.

10. McNamara M, Tzeng SC, Maier C, Zhang L, Bermudez LE. Surface proteome of
"Mycobacterium avium subsp. hominissuis" during the early stages of macrophage infection. Infect Immun. 2012; 80(5): 1868-1880.

11. Chandler JC, Sutherland MD, Harton MR, Molins CR, Anderson RV, Heaslip DG, Bosio CM, Belisle JT. Francisella tularensis LVS surface and membrane proteins as targets of effective post-exposure immunization for tularemia. J Proteome Res. 2015; 14(2): 664-675.

12. Sambrook JF, Russell DW. Molecular Cloning: A Laboratory Manual, 3rd Ed. Vols.3, Cold Spring Harbor Laboratory Press, New York; 2001: 286-301.

13. Borghesi L, Milcarek C. From B cell to plasma cell: regulation of $\mathrm{V}(\mathrm{D}) \mathrm{J}$ recombination and antibody secretion. Immunol Res. 2006; 36(1-3): 27-32.

14. Pier GB, Lyczak JB, Wetzler LM. Immunology, Infection, and Immunity. ASM Press, American; 2004: 156-172.

15. Frey A, Meckelein B, Externest D, Schmidt MA. A stable and highly sensitive 3,3',5,5'-tetramethylbenzidine-based substrate reagent for enzyme-linked immunosorbent assays. J Immunol Methods. 2000; 233(1-2): 4756.

16. Coler RN, Campos-Neto A, Ovendale P, Day FH, Fling SP, Zhu L, Serbina N, Flynn JL, Reed SG, Alderson MR. Vaccination with the $\mathrm{T}$ cell antigen Mtb 8.4 protects against challenge with Mycobacterium tuberculosis. J Immunol. 2001; 166(10): 6227-6235.

17. Billeskov R, Tan EV, Cang M, Abalos RM, Burgos J, Pedersen BV, Christensen D, Agger EM, Andersen P. Testing the H56 vaccine delivered in 4 different adjuvants as a BCG-booster in a non-human primate model of Tuberculosis. PLoS One. 2016; 11(8): e0161217.

18. Aagaard C, Hoang TT, Izzo A, Billeskov R, Troudt J, Arnett K, Keyser A, Elvang T, Andersen P, Dietrich J. Protection and polyfunctional $\mathrm{T}$ cells induced by Ag85BTB10.4/IC31 against Mycobacterium tuberculosis is highly dependent on the antigen dose. PLoS One. 2009; 4(6): e5930.

19. Gupta K, Verma I, Khuller G, Mahajan R. KatG protein: a novel marker for differential diagnosis of Mycobacterium avium complex infection. Indian J Med Microbiol. 2010; 28(3): 221-226.

20. Billeskov R, Lindenstrøm T, Woodworth J, Vilaplana C, Cardona PJ, Cassidy JP, 
Mortensen R, Agger EM, Andersen P. High antigen dose is detrimental to post-exposure vaccine protection against tuberculosis. Front Immunol. 2018; 8: 1973.

21. Brennan MJ, Thole J. Tuberculosis vaccines: a strategic blueprint for the next decade. Tuberculosis (Edinb). 2012; 92 Suppl 1: S6-S13.

22. de Paus RA, van Meijgaarden KE, Prins C, Kamphorst MH, Arend SM, Ottenhoff THM, Joosten SA. Immunological characterization of latent tuberculosis infection in a low endemic country. Tuberculosis (Edinb). 2017; 106: 62-72.

23. Tameris MD, Hatherill M, Landry BS, Scriba TJ, Snowden MA, Lockhart S, Shea JE,
McClain JB, Hussey GD, Hanekom WA, Mahomed H, McShane H; MVA85A 020 Trial Study Team. Safety and efficacy of MVA85A, a new tuberculosis vaccine, in infants previously vaccinated with BCG: a randomised, placebocontrolled phase 2b trial. Lancet. 2013; 381(9871): 1021-1028.

24. Tetramethylbenzidine [Internet]. [cited 2015 June 25]. Available from: https://en.wikipedia. org/wiki/3,3\%27,5,5\%27-Tetramethylbenzidine.

Received 16.08.2018 